\title{
Analisis Distribusi Logistik pada Pemilu 2019 di Kota Medan
}

\section{Logistic Distribution Analysis in the 2019 Election in Medan City}

\author{
Rika Mariska, Heri Kusmanto \& Fadli \\ Magister Ilmu Politik, Fakultas Ilmu Sosial Dan Ilmu Politik, Universitas Sumatera Utara, \\ Indonesia
}

Diterima: 15 Agustus 2020; Disetujui: 17 Desember 2020; Dipublish: 31 Januari 2021

\begin{abstract}
Abstrak
Penelitian ini bertujuan untuk mengeksplorasi proses distribusi logistik pemilu 2019 yang dilaksanakan KPU Kota Medan beserta kendala yang mengakibatkan proses distribusi logistik pemilu yang terlambat; menemukan jalan keluar dari terlambatnya proses distribusi logistik pemilu di Kota Medan agar sesuai prinsip tepat waktu, efektif dan efisien; dan untuk menganalisis dampak dari terlambatnya distribusi logistik pemilu terhadap integritas pemilu. Penelitian ini menggunakan metode deskriptif-kualitatif. Hasil penelitian menunjukkan bahwa banyak faktor yang menyebabkan keterlambatan distribusi logistik pemilu 2019 seperti adanya tahapan DPTHP, kekurangan armada, kebijakan yang diambil untuk distribusi dari PPS di kelurahan ke TPS pada tanggal 17 April 2019 sebelum dimulainya pemungutan suara, dan lainnya.Terdapat dua metode yang ditawarkan sebagai jalan keluar dari masalah tersebut: satu, Distribusi tetap dari KPU ke PPS dan terakhir ke TPS; dua, Menggunakan pusat distribusi (gudang) di lima daerah pemilihan di Kota Medan untuk memecah konsentrasi tidak pada satu tempat agar meringankan pekerjaan, lebih fokus, serta meminimalisir terjadinya keterlambatan logistik dan tertukarnya surat suara antar daerah pemilihan. Keterlambatan logistik menunjukkan adanya human error, kurangnya kapasitas dan kemampuan penyelenggara pemilu.
\end{abstract}

Kata Kunci: Distribusi Logistik Pemilu; Pemilu 2019; Integritas Pemilu.

\begin{abstract}
This study aims to explore the 2019 election logistics distribution process carried out by the KPU of Medan City along with the obstacles that resulted in the late election logistics distribution process; finding a way out of the delay in the distribution process of election logistics in Medan City so that it is in accordance with the principles of being on time, effectively and efficiently; and to analyze the impact of late distribution of election logistics on the integrity of elections. This study used descriptive qualitative method. The results showed that many factors caused delays in the distribution of the 2019 election logistics, such as the DPTHP stage, fleet shortages, policies taken for distribution from PPS in urban villages to polling stations on April 17, 2019 before the start of voting, and others. as a way out of these problems: one, permanent distribution from KPU to PPS and finally to TPS; two, Using distribution centers (warehouses) in five constituencies in Medan City to break the concentration from one place in order to ease the work, be more focused, and minimize the occurrence of logistical delays and the exchange of ballots between electoral districts. Logistical delays indicate human error, lack of capacity and capability of election administrators. Keywords: Election Logistics Distribution; 2019 Elections; Election Integrity.
\end{abstract}

How to Cite: Mariska, M., Kusmanto, H., \& Fadli. (2021). Analisis Distribusi Logistik pada Pemilu 2019 di Kota Medan. PERSPEKTIF, 10 (1): 110-119.

*Corresponding author: ISSN 2085-0328 (Print)

E-mail: rikamariska12@gmail.com ISSN

(Online) 


\section{PENDAHULUAN}

Pemilu yang berintegritas adalah pemilu yang berdasarkan prinsip demokrasi dari hak pilih universal serta adanya kesetaraan di bidang politik sebagaimana tercermin dalam standar dan perjanjian internasional, profesional serta tidak memihak dan transparan dalam persiapan dan administrasi di seluruh siklus pemilu (Annan, 2012). Tanpa integeritas pemilu, maka para pemimpin dan pejabat negara tidak memiliki akuntabilitas kepada publik, lemahnya kepercayaan publik terhadap hasil pemilu, dan pemerintah tidak memiliki legitimasi yang diperlukan (Ace, https://aceproject.org/ace-

en/topics/ei/introduction/ei20). Integritas pemilu membutuhkan sistem hukum dan kelembagaan yang mendorong dan melindungi pemilu yang adil dan merata serta penerapan langkah-langkah spesifik untuk melindungi integritas berdasarkan standar pemilu yang demokratis dan praktik terbaik.

Pemilu merupakan bagian dasar yang tidak dapat terpisahkan dari demokrasi. Integritas penyelenggaraan dalam semua tahapan Pemilu menjadi hal penting yang harus diperhatikan oleh penyelenggara Pemilu yakni KPU dan Bawaslu (DKPP, 2015)Pemilu dilaksanakan dalam suasana keterbukaan dengan kebebasan berpendapat yang hasilnya mencerminkan aspirasi masyarakat. Ajang 5 tahun sekali ini telah dilaksanakan sebanyak dua belas kali sejak kemerdekaan Indonesia tahun 1945 hingga tahun 2019, yaitu pemilihan umum tahun1955, tahun 1971, tahun 1977, tahun 1982, tahun 1987, tahun 1992, tahun 1997, tahun 1999, tahun 2004, tahun 2009, tahun 2014 dan tahun 2019. Sejalan dengan pelaksanaan pemilu-pemilu tersebut dapat terlihat adanya upaya mencari sistem pemilu yang sesuai untuk Indonesia.

Pemilu tahun 2019 merupakan pelaksanaan pemilihan umum serentak yang pertama kali diadakan di Indonesia, yakni pelaksanaan pemilihan umum Presiden dan Wakil Presiden serentak dengan pemilihan umum anggota DPR, DPD, dan DPRD. Pelaksanaannya tersebut serentak pada tanggal 17 April 2019. Gagasan Pemilu serentak tahun 2019 adalah hasil dari putusan Mahkamah Konstitusi No. 14/PUU-XI/2013 mengenai pengabulan sebagian permohonan uji materi (judicial review) atas UndangUndang No. 42 Tahun 2008 tentang Pemilihan
Umum Presiden dan Wakil Presiden. Semangat dari dilaksanakannya pemilu serentak menurut Mahkamah Konstitusi adalah lebih hemat biaya, selain itu dapat menghemat waktu dan menekan konflik atau gesekan horizontal di masyarakat pada masa pemilu. Bukan itu saja, dengan pemilu serentak maka setiap warga negara dapat menggunakan hak pilihnya secara cerdas dan efisien.

Pemilu merupakan suatu proses konversi suara rakyat menjadi kursi penyelenggara negara. Untuk itu diperlukan suatu sistem pemilu (electoral systems), proses tahapan pemilu (electoral processes), dan logistik pemilu (Surbakti, 2011). Salah satu tahapan pendukung tapi merupakan salah satu faktor penentu terselenggaranya Pemilu adalah tahapan logistik. Proses logistik pada Pemilu tahun 2019 didasarkan pada Peraturan Komisi Pemilihan Umum Nomor 15 Tahun 2018. Dalam pasal 3 peraturan tersebut pengadaan perlengkapan penyelenggaraan Pemilu dilaksanakan berdasarkan prinsip tepat jumlah, tepat jenis, tepat sasaran, tepat waktu, tepat kualitas, dan efisiensi.

Pada pasal 27 ayat (1), (2) dan (3) berturut-turut menyatakan untuk pengadaan yang dilaksanakan oleh KPU berupa kotak suara, bilik suara, surat suara, segel, hologram, tinta, template tunanetra, DPC Presiden, DCT DPR dan DPD serta formulir. Pengadaan yang dilaksanakan oleh KPU Provinsi berupa sampul, form salinan, form lainnya, DCT DPRD Provinsi dan DPRD Kabupaten/Kota. Sedangkan pengadaan perlengkapan Pemilu 2019 yang dilaksanakan oleh KPU Kabupaten/Kota antara lain: buku panduan, salinan DPT, dan alat kelengkapan TPS. Proses pelaksanaan pengadaan perlengkapan penyelenggaraan Pemilu 2019 berpedoman kepada Perpres No. 16 Tahun 2018.

Walaupun rancangan KPU dalam bentuk peraturan dan keputusan untuk proses pengelolaan logistik sudah baik akan tetapi masih terdapat berbagai permasalahan terjadi selama proses tahapan penyelenggaraan pemilu 2019. Sebagai peringatan dini kepada KPU, Bawaslu telah menyusun IKP (Indeks Kerawanan Pemilu) 2019. Dalam pemutakhiran IKP pada Maret 2019, terdapat lima isu strategis nasional. Untuk posisi kerawanan tertinggi kedua dengan persentase sebesar 47 persen yang terjadi di 244 kabupaten/kota dari 514 Kabupaten/Kota di 
Indonesia diduduki Logistik Pemilu (Bawaslu, 2019). Untuk tahapan distribusi logistik, pada tanggal 16 April 2019 pukul 21.00 waktu setempat. Bawaslu menerima laporan adanya KPPS yang belum menerima perlengkapan pemungutan dan penghitungan suara (17.033 laporan) (Abhan, 2019) Laporan tersebut belum termasuk laporan saat proses pemungutan dan penghitungan suara.

Keterlambatan logistik merupakan masalah yang krusial bukan saja pada penyelenggaraan pemilu tahun 2019 tapi juga pada pelaksanaan-pelaksanaan pemilu yang lalu. Pada penyelenggaraan pemilu serentak tahun 2019, keterlambatan logistik sampai ke KPU Kabupaten/Kota berdampak pada terganggunya jadwal tahapan sortir/lipat surat suara, pengepakan dan distribusi logistik ke TPS. Berakibat pada tertundanya pelaksanaan pemungutan dan penghitungan suara di TPS. Sehingga sejumlah 2.767 TPS melaksanakan pemungutan suara ulang, susulan, dan pemungutan suara lanjutan yang sebagiannya disebabkan masalah logistik (Farisa, 2019). Selain terjadinya pemungutan suara ulang, susulan dan lanjutan tersebut. Keterlambatan distribusi logistik juga berakibat pada adanya aduan yang masuk ke DKPP (Dewan Kehormatan Penyelenggara Pemilu) terhadap penyelenggara pemilu yang dianggap melanggar kode etik. Jika dikaitkan dengan tahapan distribusi logistik, maka proses distribusimelibatkan PPK, PPS dan KPPS sebagai penerima logistik di TPS.Evaluasi logistik hanya sebatas evaluasi diatas kertas sebagai daftar inventaris masalah, rapat kerja maupun rapat koordinasi yang dilaksanakan kebanyakan membahas masalah anggaran yang kurang. Namun belum ada kebijakan untuk mengatasi masalah tersebut. Bukan itu saja, adanya badan adhoc yang meninggal yang sebagian besar disebabkan kelelahan merupakan salah satu hal yang perlu menjadi perhatian. Untuk Kota Medan, terdapat 4 orang KPPS dan 4 orang petugas ketertiban.

Kota Medan merupakan ibukota Provinsi Sumatera Utara. Kota Medan memiliki 21 (dua puluh satu) Kecamatan dan 151 (tiga puluh lima) Kelurahan, dengan jumlah TPS sebanyak 6.392 TPS dan 7 TPS tambahan untuk rumah tahanan yang ada di wilayah administrasi Kota Medan pada Pemilu 2019. Luas wilayah 265,10 km2. Secara administratif Kota Medan di sebelah utara berbatasan dengan Selat Malaka, sebelah timur, selatan dan barat berbatasan dengan Kabupaten Deli Serdang. Pendistribusian logistik kebutuhan Pemilu 2019 Kota Medan tiba di kelurahan pukul 04.00 WIB tanggal 17 April 2019 yang mengakibatkan sekitar 35\% TPS di Kota Medan tidak dapat memulai pemungutan dan penghitungan suara pada pukul 07.00 WIB di hari pemungutan dan penghitungan suara (Bawaslu K. M., 2019). Sebagai contoh dikutip dari media online, terdapat keterlambatan dimulainya pemungutan suara di TPS 112 Kompleks Citra Wisata Medan Johor dikarenakan kotak suara tiba di lokasi pada pukul 07.30 WIB. Dari persentase tersebut yang paling lama memulai pemungutan dan penghitungan suara pada pukul 10.00 WIB. Ditinjau dari Undang-Undang No. 7 Tahun 2017 tentang Pemilihan Umum pada pasal 341 ayat 6 dinyatakan bahwa "perlengkapan pemungutan suara harus sudah diterima KPPS paling lambat 1 (satu) hari sebelum hari pemungutan suara". Masalah tata kelola logistik perlu mendapat perhatian khusus secara nasional karena dapat mengganggu jalannya proses pemilu.

\section{METODE PENELITIAN}

Penelitian ini menggunakan metode penelitian kualitatif. Penelitian kualitatif merupakan metode-metode untuk mengeksplorasi dan memahami makna yang berasal dari masalah sosial dan kemanusiaan. Pada penelitian kualitatif, dalam melihat suatu realita secara alamiah,apa adanya sesuai dengan hukum alam, menggunakan metode triangulation yakni gabungan antara sumber data, peneliti dan teori, serta secara hubungan peneliti dan yang diteliti tidak dapat dipisahkan (Bungin, 2015). Peneliti merupakan instrumen instrumen kunci dalam pengumpulan data, dimana peneliti mengumpulkan sendiri data-data baik melalui observasi, wawancara dan dokumentasi (Creswell, 2016). Jenis penelitian yang digunakan adalah penelitian deskriptif, atau pada umumnya disebut deskriptif-kualitatif. Penggunaan jenis penelitian deskriptif dalam penelitian ini dengan maksud untuk melukiskan, menggambarkan atau 
memaparkan objek yang diteliti apa adanya, sesuai dengan situasi dan kondisi ketika penelitian dilakukan. Dengan menggunakan jenis penelitian deskriptif, diharapkan peneliti dapat mendeskripsikan kendala-kendala yang dialami dalam distribusi logistik pada Pemilu 2019 di Kota Medan. Peneliti menemukan solusi dari masalah tersebut dan mendeskripsikan dampak dari terlambatnya distribusi logistik terhadap integritas pemilu.

Penelitian ini difokuskan pada masalah keterlambatan distribusi logistik dan ketidaktersediaan surat suara pemilihan presiden dan wakil presiden di kotak suara pada Pemilu 2019. Penelitian ini dilakukan di Kota Medan Provinsi Sumatera Utara. Dari empat jenis strategi pengumpulan data yang diungkapkan (Creswell, 2016). Pada penelitian ini strategi pengumpulan data yang digunakan adalah metode wawancara, dokumentasi dan observasi. Peneliti melakukan wawancara secara mendalam terhadap informan. Dokumentasi dilakukan dengan cara mengumpulkan laporan kegiatan, bahan-bahan tertulis lainnya yang berhubungan dengan topik penelitian. Sedangkan observasi digunakan untuk melihat kondisi lapangan yang membantu dalam proses penelitian. Data yang digunakan dalam penelitian ini adalah data primer dan data sekunder. Data primer adalah data yang diperoleh secara langsung dari subjek penelitian sebagai sumber informasi yang dicari. Sedangkan data sekunder adalah data yang diperoleh secara tidak langsung dari sumber penelitian (Azwar, 2010). Data primer berupa script wawancara terhadap informan. Data sekunder berupa dokumen-dokumen distribusi logistik Pemilu 2019, serta sumber bahan bacaan lainnya.

Penelitian ini menggunakan informan kunci dalam proses pengumpulan data. Informan kunci dalam penelitian ini yaitu:

a) Kasubbag Keuangan, Umum dan Logistik KPU Kota Medan;

b) Ketua PPK Kecamatan Medan Johor;

c) Ketua PPS Kelurahan Pangkalan Manshur Kecamatan Medan Johor;

d) Ketua KPPS TPS 112 Kelurahan Pangkalan Manshur Kecamatan Medan Johor;

e) Bawaslu Kota Medan;

f) Pakar Logistik;

g) 3 orang tokoh masyarakat.
Adapun jenis penelitian yang digunakan adalah deskriptif-kualitatif, maka proses analisis data dimulai dengan menelaah data yang diperoleh, kemudian dianalisis dengan menggunakan teori sebagai alat analisis data. Sehingga dapat ditemukan makna, kata kunci, alur kontekstual yang menjelaskan apa yang terjadi di balik terlambatnya distribusi logistik di Kota Medan. Sedangkan untuk mencari solusi dari terlambatnya logistik menerapkan model Diamond Porter, untuk menganalisis indikator-indikator penghambat proses distribusi, sehingga diperoleh alternatif cara dalam proses distribusi logistik.

\section{HASIL DAN PEMBAHASAN}

Distribusi merupakan aktivitas pergerakan barang dan jasa dari pemasok hingga konsumen akhir (Abushaikha, 2018) melalui distribution channel (saluran distribusi), dengan menghasilkan nilai tambah (value added) melalui pengiriman barang ke lokasi konsumen, pada waktu dibutuhkan, utilisasi alat dan efisiensi biaya. Pada Pemilu Tahun 2019 KPU Kota Medan mulai melaksanakan distribusi logistik pada $\mathrm{H}-4$ atau tanggal 13 April 2019. Alur pendistribusian logistik KPU Kota Medan Pada Pemilu 2019 dimulai dari KPU kota Medan menyalurkan logistik kepada PPS di seluruh Kelurahan Kota Medan kemudian dilanjutkan kepada KPPS di TPS. Proses distribusi perlengkapan pemungutan suara yang dilaksanakan KPU Kota Medan menggunakan pusat distribusi dan sistem cross docking. Untuk gudang, KPU Kota Medan menyewa gedung Andromeda ex. Bandara Polonia Medan. Alasan pemilihan gedung tersebut selain faktor lokasi yang strategis tepat di tengah kota, luas bangunan juga faktor keamanan, karena terletak di wilayah TNI AU. Hal senada juga diungkapkan oleh PPK dan PPS yang diwawancarai.

Menurut Henrique Albernaz, ciri-ciri dari pusat distribusi sama seperti gudang yang terdapat di lokasi strategis dengan fungsi yang ditentukan oleh perusahaan, didalamnya terjadi penerimaan barang dari satu atau lebih penyedia, kemudian dilakukan pembagian menjadi kelompok yang lebih kecil sehingga pada akhirnya dapat dikirim ke pelanggan akhir dengan lokasi yang terdekat (Albernaz, 2014). Fungsi dari pusat distribusi antara lain: penerimaan, penanganan, penyimpanan, pengambilan pesanan, dan terakhir 
pengiriman, dengan kata lain ketika barang diterima di pusat distribusi, maka barang dapat disimpan atau langsung dikirim ke tujuan akhir (cross-docking). KPU Kota Medan menjadikan 151 (seratus lima puluh satu) kantor kelurahan sebagai pusat distribusi. Distribusi tidak melalui proses bongkar muat di kantor kecamatan karena kota Medan dari segi jarak dekat. Distribusi logistik dari kantor kelurahan kemudian dilanjutkan ke TPS (Tempat Pemungutan Suara) di masingmasing kelurahan pada tanggal 17 April 2019 pagi. Pemilihan pagi hari tersebut sebagai waktu distribusi logistik ke TPS, menurut PPS dan KPPS yang diwawancarai karena faktor keamanan kotak suara.

KPU Kota Medan dalam mendistribusikan logistik pemilu 2019 di Kota Medan dari gudang logistik ke PPS di kantor kelurahan menggunakan armada truk fuso/ truk engkel 6 roda dan pick up L 300. Dengan jumlah muatan pada truk fuso sebanyak 280 buah kotak suara dan 1.500 buah bilik suara. Sedangkan untuk muatan pick up L 300 sebanyak 75 buah kotak suara dan 750 buah bilik suara. kemudian dari kantor kelurahan ke TPS, KPPS mengambil kotak suara dengan armada yang disewa masing-masing KPPS. Ada yang menggunakan pick up, mobil pribadi dan becak. Selama distribusi logistik pemilu 2019, cuaca tidak selalu cerah, terdapat hujan di beberapa wilayah sehingga ada beberapa kotak suara yang bentuknya sudah tidak sesuai, namun dapat diatasi. Kecamatan yang terjauh di Kota Medan yang ditinjau dari segi jarak antara gudang logistik adalah Kecamatan Medan Belawan dengan jarak tempuh sekitar satu jam perjalanan. Kecamatan yang susah dilalui cenderung tidak ada. Pemerintah Kota Medan berperan dalam distribusi logistik pemilu 2019 dengan mengerahkan Satpol PP (Satuan Polisi Pamong Praja), dinas perhubungan, dinas kebersihan, perangkat di kelurahan dan P3SU (Petugas Penanganan Prasarana dan Sarana Umum). Ada berbagai faktor keterlambatan logistik pemilu 2019 di Kota Medan. Salah satunya adalah kekurangan logistic seperti surat suara dan formulir model CI Plano.

Pengadaan perlengkapan pemungutan dan penghitungan suara terbagi atas 3 (tiga) pelaksana, antara lain: a) KPU. Jenis logistik yang diadakan berupa kotak suara, bilik suara, surat suara, segel, hologram, tinta, template tunanetra, DPC Presiden, DCT DPR dan DPD serta formulir;

b) KPU Provinsi. Jenis logistik yang diadakan berupa sampul, form salinan, form lainnya, DCT DPRD Provinsi dan DPRD Kabupaten/Kota;

c) KPU Kabupaten/Kota. Jenis logistik yang diadakan KPU Kab/Kota antara lain buku panduan, salinan DPT, dan alat kelengkapan TPS.

Faktor kekurangan surat suara ini akibat dari tahapan DPTHP (Daftar Pemilih Tetap Hasil Perbaikan). Setelah DPT (Daftar Pemilih Tetap) ditetapkan pada tanggal 21 Agustus 2018, masih ada jadwal DPTHP dan DPTb (Daftar Pemilih Tetap tambahan) yang merupakan penentu jumlah surat suara yang harus dicetak. Adapun tahapannya sebagai berikut (Bawaslu K. M., 2019):

a) Penetapan DPT (Daftar Pemilih Tetap)

Berita Acara No. 73/PL.02.1BA/1271/KPU.Kot/VIII/2018.

Tanggal 21 Agustus 2018.

Jumlah TPS sebanyak 6.349.

Jumlah DPT sebanyak 1.579.354 orang dengan rincian laki-laki sebanyak 774.952 orang dan perempuan sebanyak 804.402 orang.

b) Penetapan DPTHP 1 (Daftar Pemilih Tetap Hasil Perbaikan tahap 1)

Berita Acara No. 81/PL.02.1BA/1271/KPU.Kot/IX/2018.

Tanggal 13 September 2018.

Jumlah TPS sebanyak 6.349.

Jumlah DPTHP 1 sebanyak 1.570 .327 orang dengan rincian laki-laki sebanyak 770.578 orang dan perempuan sebanyak 779.749 orang.

c) Penetapan DPTHP 2 (Daftar Pemilih Tetap Hasil Perbaikan tahap 2)

Berita Acara No. 226/PP.09.1BA/1271/KPU.Kot/XII/2018.

Tanggal 09 Desember 2018.

Jumlah TPS sebanyak 6.392.

Jumlah DPTHP 2 sebanyak 1.614 .673 orang dengan rincian laki-laki sebanyak 791.316 orang dan perempuan sebanyak 823.357 orang. 
d) Penetapan DPTb 1 (Daftar Pemilih Tambahan tahap 1)

Berita Acara No. 42/PL.02.1BA/1271/KPU.Kot/II/2019.

Tanggal 16 Februari 2019.

Jumlah TPS sebanyak 6.392.

Jumlah masuk DPTb sebanyak 2.537 dan keluar sebanyak 1.418 orang

e) Penetapan DPTb 1 (Daftar Pemilih Tambahan tahap 2)

Berita Acara No. 75/PL.02.1BA/1271/KPU.Kot/III/2019.

Tanggal 20 Maret 2019.

Jumlah TPS sebanyak 6.392 .

Jumlah masuk DPTb sebanyak 5497 dan keluar sebanyak 8.391 orang

f) Penetapan DPTHP 3 (Daftar Pemilih Tetap Hasil Perbaikan tahap 3)

Berita Acara No. 88/PP.09.1BA/1271/KPU.Kot/IV/2019.

Tanggal 03 April 2019.

Jumlah TPS sebanyak 6.392.

Jumlah DPTHP 2 sebanyak 1.615 .920 orang dengan rincian laki-laki sebanyak 792.479 orang dan perempuan sebanyak 823.441 orang.

Dari hasil DPTb maka terdapat penambahan TPS basis DPTb sebanyak 7 TPS untuk rutan/lapas. Selain karena faktor DPT yang diperbaiki beberapa kali, faktor jumlah SDM dan ketersediaan armada transportasi juga merupakan faktor penentu dari keterlambatan logistik.

Tata kelola pemilu adalah serangkaian kegiatan yang menciptakan dan memelihara kerangka kerja institusi/lembaga dalam proses pemungutan suara dan berlangsungnya kompetisi pemilu. Tata kelola pemilu bekerja pada tiga tingkatan yakni pembuatan peraturan, penerapan peraturan dan ajudikasi aturan (Torres, 2015). Dalam proses pelaksanaan distribusi logistik, tata kelola pemilu berada pada tingkat penerapan aturan. Tata kelola pemilu pada tingkat implementasi peraturan mengkoordinasikan tugas-tugas dari berbagai personel dan mengorganisasi berbagai kegiatan yang kompleks dan saling tergantung dengan membangun dasar kelembagaan stabil untuk pemungutan suara dan kompetisi pemilu. Pada tingkatan ini, tata kelola pemilu sebagai pengaplikasian peraturan menimbulkan suatu citra yang ideal dari pelaksanaan rutin dan mekanisme birokrasi dari serangkaian aturan dan pelaksanaan aturan yang diketahui serta diuji secara koheren (Mozaffar, 2002). Dari segi tata kelola pemilu pada tingkatan implementasi peraturan, maka telah disebutkan diatas, bahwa KPU Kota Medan belum melakukan implementasi peraturan dengan baik. Belum dapat melakukan koordinasi berbagai kegiatan yang kompleks dalam membangun dasar kelembagaan yang stabil untuk pemungutan suara dan kompetisi pemilu.

\section{Solusi dalam Mengatasi Masalah Distribusi Logistik Agar Sesuai Prinsip Tepat Waktu, Efektif dan Efisien}

Agar proses distribusi berjalan sesuai peraturan maka diperlukan persiapan yang matang. Untuk itu, penulis mencoba memberikan solusi proses distribusi, agar keterlambatan logistik tidak terulang pada pemilu mendatang. Salah satu metode yang dapat digunakan yaitu Distribusition Requirment Planning (DRP). Kemudian dilakukan kajian mendalam dari dua model metode DRP yang ditawarkan, model mana yang efektif dan efisien. Efektif berhubungan dengan kecepatan dan waktu, sedangkan efisien berhubungan dengan biaya. Semakin cepat waktunya maka biaya semakin mahal.

\section{Distribution Requirment Planning (DRP) 1}

Tahapan distribusi yang ditawarkan masih menggunakan tahapan yang terdapat dalam peraturan dan keputusan KPU. Hanya saja dibutuhkan perencanaan yang lebih matang dan rinci. KPU Kota Medan sudah membuat jadwal distribusi, hanya saja yang terjadi di lapangan berbeda dengan jadwal yang telah dibuat. Pertimbangannya adalah jumlah DPT (Daftar Pemilih Tetap) yang terus bertambah diikuti dengan penambahan jumlah TPS, penambahan logistik kotak suara tiap TPS serta jarak tempuhnya. Pada tahapan distribusi ini, KPU Kota Medan harus dapat memastikan kelengkapan logistik sebelum dimulainya proses distribusi, kebutuhan jumlah SDM, luas gudang, kebutuhan jumlah dan jenis kendaraan distribusi, dan yang paling penting sudah dapat memastikan jumlah anggaran yang dibutuhkan. 
Gambar 1. Distribution Requirment Planning (DRP) 1 Sumber: Peneliti

Gambar 1 menjelaskan bahwa pusat distribusi terdapat di setiap kelurahan. Gudang logistik terdapat pada KPU Kota Medan. Di setiap kantor lurah dilakukan proses cross docking. Dengan kata lain pada setiap kantor kelurahan dilakukan proses bongkar muat dan pindah angkutan untuk pengantaran ke titik berikutnya sampai ke titik akhir di TPS. Untuk pelaksanaan distribusi, terlebih dahulu harus diketahui jarak kecamatan terjauh dan kecamatan yang susah dijangkau, luas wilayah serta kondisi geografis. Kota Medan memiliki luas wilayah 265,10 $\mathrm{km}^{2}$. Kondisi geografis kota Medan berupa daratan yang mudah dilalui. Selain itu juga perlu diketahui jumlah kotak dan bilik suara di tiap kecamatan serta jumlah muatan dalam tiap armada agar diketahui berapa jumlah armada yang harus digunakan dan berapa trip perjalanan untuk satu armada.

\section{Distribution Requirment Planning (DRP) 2}

Tahapan distribusi dalam DRP 2 ini menawarkan alternatif berbeda dari yang pernah ada dengan tujuan untuk memecah konsentrasi pada satu gudang menjadi lima gudang. Dengan dilakukan pemecahan konsentrasi kerja maka setiap pekerjaan yang sama dapat dilakukan dalam satu waktu dan pengawasan yang ketat dapat terlaksana. DRP 2 ini dapat memberikan perubahan dalam peraturan dan keputusan KPU terkait distribusi.

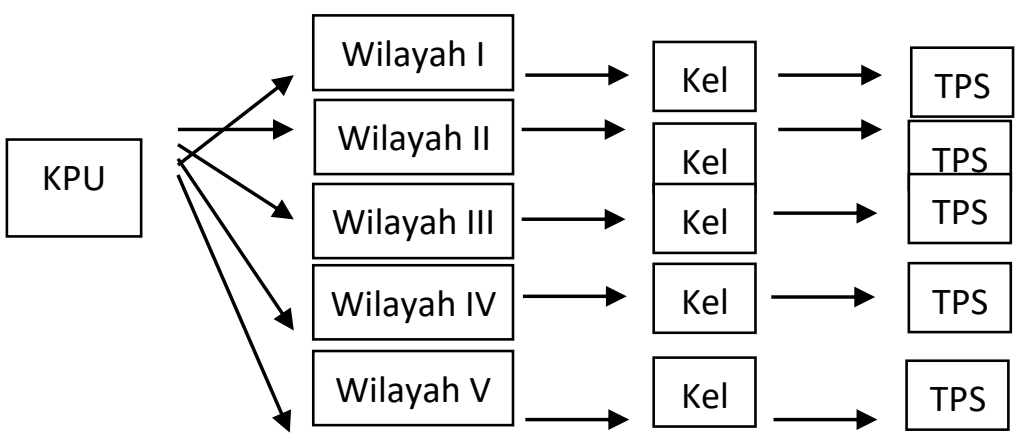

Gambar 2. Distribution Requirment Planning (DRP) 2 Sumber: Peneliti

Pelaksanaan distribusi pemilu yang ditawarkan dengan menggunakan pusat distribusi dan sistem cross docking. Penetuan pusat distribusi harus mempertimbangkan sebaran geografis. Faktor lokasi sangat penting dalam pengambilan keputusan pusat distribusi. Semakin tersebar lokasi konsumen, maka semakin luas pula jangkauan-jangkauan barang. Sehingga perlunya dipertimbangkan lokasi yang dekat dengan konsumen (weight gaining) (Martono, 2018). Aksesibilitas merupakan salah satu satu pendorong utama dalam pemilihan lokasi pusat distribusi (Onstein, 2019). Dalam menentukan lokasi pusat distribusi terdapat kerangka konsep yang terdiri dari tiga tahap seleksi (Van Thai, 2005), antara lain: a) indentifikasi area geografis secara umum; b) identifikasi situssitus/tempat-tempat alternatif; dan c) pemilihan situs tertentu.

Penanggung jawab pada setiap gudang adalah PPK-PPS dan sekretariat setiap daerah 
pemilihan dibantu dengan pihak kepolisian dalam menjaga gudang. Proses kerjanya, setiap logistik yang diterima oleh KPU Kota Medan langsung dilakukan penghitungan dan bongkar muat barang sesuai dengan jumlah kebutuhan setiap daerah pemilihan. Alat kelengkapan logistik selain surat suara dan formulir dapat langsung dikirim ke masing-masing gudang. Sedangkan lipat sortir surat suara dan sortir formulir dilakukan di gudang KPU. setelah proses lipat sortir surat suara dan sortir formulir, maka surat suara dan formulir dikirim ke masing-masing gudang yang selesai untuk langsung dilakukan pengepakan kotak suara. Proses pengepakan surat suara dan formulir dilaksanakan oleh PPK, PPS dan sekretariat serta diawasi langsung oleh KPU Kota Medan.

\section{Dampak Keterlambatan Logistik Pemilu 2019 di Kota Medan terhadap Integritas Pemilu}

Membahas mengenai pemilihan yang berintegritas artinya merujuk pada pemilihan yang dilakukan secara kompeten dan profesional. Ditinjau dari teori yang dipaparkan dalam aceproject.org terdapat lima tantangan yang dihadapi untuk menciptakan pemilu yang berintegritas, salah satunya adalah terdiri atas badan pengelola pemilu (EMB) yang profesional, kompeten, dengan kemandirian dan tindakan penuh untuk menyelenggarakan pemilihan yang transparan dan pantas mendapatkan kepercayaan public. Dalam penelitian ini konsep integritas pemilu dilihat dari sudut pandang tata kelola pemilu yang dilaksanakan oleh lembaga pemilu yaitu KPU Kota Medan dalam tahapan distribusi logistik pemilu 2019. Salah satu prinsip logistik yakni tepat waktu yang terdapat dalam Peraturan Komisi Pemilihan Umum Nomor 15 Tahun 2018 disandingkan dengan prinsip panduan yang dapat membantu menwujudkan pemilu yang berintegritas yang salah satunya adalah profesional dan akurasi (Ace, https://aceproject.org/aceen/topics/ei/introduction/ei20 ).

Hasil dari wawancara dari tiga orang tokoh masyarakat didapat bahwa keterlambatan logistik ke TPS dikarenakan faktor diluar jangkauan KPU Kota Medan. KPU Kabupaten/Kota hanya menunggu barang yang diadakan oleh KPU RI dan KPU Provinsi. Hal ini berpengaruh pada terlambatnya proses pengepakan kotak suara. Sehingga jumlah SDM yang digunakan untuk pengepakan dianggap kurang karena waktu untuk pengepakan yang menjadi singkat. Jadwal yang telah ditetapkan ikut berubah ketika di lapangan. Seperti yang dikatakan oleh Nazir Salim Manik, "Isu logistik dianggap belum penting, belum dijadikan salah satu item menjaga kualitas pemilu oleh peserta pemilu." Isu logistik adalah isu yang nomor sekian. Adanya kontradiktif antara peraturan KPU dengan surat edaran serta adanya mis administrasi dimana ada kebijakan yang dilaksanakan berbeda dengan kebijakan hulunya.

Dalam menyelenggarakan pemilu yang kredibel terdapat empat tugas yang harus dipenuhi, antara lain: a) Administrasi yang netral, transparan dan profesional dipertahankan; b) Mengadopsi prosedur untuk menjaga integritas operasinya; c) Melakukan identifikasi dan penilaian resiko terhadap integritas serta mengambil tindakan yang korektif dan preventif; d) Mempromosikan kesadaran pemilih akan integritas pemilu.

Dari keempat tugas tersebut, menurut Safrin sebagai tokoh masyarakat 2 belum sepenuhnya terlaksana, khususnya mempromosikan kesadaran pemilih akan integritas pemilu. informan melanjutkan bahwa profesional dan kompetensi penyelenggara pemilu 2019 bisa dikatakan diragukan bila dilihat dari keterlambatan logistik. Tibanya logistik yang tepat waktu akan menunjukkan bahwa penyelenggara pemilu bekerja secara profesional dan kompeten. Keterlambatan logistik menunjukkan adanya human error dan kurangnya kapasitas dan kemampuan penyelenggara pemilu.

Pernyataan berbeda datang dari tokoh masyarakat 3. Ishaq yang merupakan anggota DPRD Kota Medan ini menjelaskan bahwa pemilu yang berintegritas merupakan pemilu yang terselenggara dengan jujur, komitmen dan konsisten. Pemilu berintegritas tidak secara otomatis datang dari penyelenggara yang berintegritas. Ada faktor money politic yang sulit dibuktikan dan masih terjadi. Money politic hanyalah salah satu contoh persoalan yang sampai saat ini belum bisa hilang dan menjadikan sebab pemilu tidak berintegritas. Jadi tidak hanya penyelenggara pemilu, tetapi seluruh pihak yang terlibat di dalam kepemiluan tersebut, baik itu penyelenggara, 
peserta, masyarakat pemilih dan semua pihak yang terkait haruslah berintegritas, sehingga akan terwujudlah yang dinamakan Pemilu Berintegritas.Di dalam Undang-undang Nomor 7 tahun 2017 tidak mengatur dan disebutkan secara khusus tentang integritas, tetapi meninjau dari definisi-definisi diatas maka sebagai penyelenggara, peserta maupun pemilih harus mematuhi peraturan (regulasi) yang mengatur tentang pemilu. Baik itu undang-undang, Peraturan KPU, Peraturan Bawaslu maupun Peraturan DKPP. Jika masih terjadi keterlambatan dalam pendistribusian logistik maka hal tersebut tidak dapat dikatakan sebagai pemilu yang berintegritas karena dapat dilihat bahwa KPU Kota Medan tidak bekerja secara professional dan perlunya dilakukan evaluasi dan proyeksi agar hal tersebut tidak terjadi kembali, akan lebih efektif apabila KPU Kota Medan memiliki plan atau rencana kedua apabila terjadi permasalahan untuk mencegah keterlambatan dalam pendistribusian logistik. Banyaknya kecurangan dalam proses pemilu tidak sepenuhnya menjadi kesalahan dari KPU Kota Medan, maka dari itu perlunya kesadaran dan pengawasan dalam proses pemilu itu sendiri oleh masyarakat dan tokoh-tokoh setempat agar pemilu berintegritas dapat terlaksana serta perlunya untuk memberikan pendidikan atau memilih PPK/ PPS sesuai dengan kriteria yang memadai agar tidak terjadi tindak kecurangan / human errordalam proses pemilu.

\section{SIMPULAN}

KPU Kota Medan mendistribusikan logistik ke kelurahan, karena dari segi jarak Kota Medan dekat. Sehingga tidak terjadi bongkar muat di kantor kecamatan.Petugas KPPS (Kelompok Penyelenggara Pemungutan Suara) mengambil kotak suara di kantor/aula kelurahan pada tanggal 17 April 2019 dengan alasan faktor keamanan.KPU Kota Medan menggunakan ex. Bandara Polonia sebagai gudang logistik karena faktor keamanan, karena berada di kawasan TNI AU.KPU Kota Medan mendistribusikan logistik menggunakan armada turk Fuso dan Pick Up L 300.Kecamatan Medan Belawan merupakan Kecamatan terjauh.Keterlambatan distribusi logistik pemilu 2019 di Kota Medan mengakibatkan 35\% TPS di Kota Medan tidak dapat memulai pemungutan suara pada tanggal 17 April 2019 pukul 07.00 WIB.Keterlambatan dikarenakan adanya tahapan DPTHP sehingga mengakibatkan kekurangan surat suara yang pada hari pendistribusian masih terjadi sortir lipat surat suara dan pengepakan. Jadwal yang telah dibuat menjadi berubah di lapangan. Pemerintah Kota Medan berperan dalam distribusi logistik dengan mengerahkan Satpol PP (satuan Polisi Pamong Praja), dinas perhubungan, dinas kebersihan dengan bantuan truk sampah dan P3SU (Petugas Penanganan Prasarana dan Sarana Umum). Keterlambatan logistik menunjukkan adanya human error dan kurangnya kapasitas dan kemampuan penyelenggara pemilu.Naik atau turunnya integritas pemilu tidak hanya datang dari kinerja penyelenggara pemilu, tapi ada faktor luar yaitu money politic.

\section{DAFTAR PUSTAKA}

Abhan, D. (2019). Serial Evaluasi Penyelenggara Pemilu Serentak 2019: Perihal Para Penyelenggara Pemilu. Jakarta: Bawaslu.

Abushaikha, I. (2018). The Influence of Logistics Clustering on Distribution Capabilities: A Qualitative Study. International Journal of Retail and Distribution Management , 46 (6), 580-581.

Ace. (n.d.). https://aceproject.org/aceen/topics/ei/introduction/ei20 . Retrieved Maret 08, 2020, from https://aceproject.org: https://aceproject.org/aceen/topics/ei/introduction/ei20

Ace. (n.d.). https://aceproject.org/aceen/topics/ei/introduction/ei20 . Retrieved Maret 2020, 2020, from https://aceproject.org/aceen/topics/ei/introduction/ei20: https://aceproject.org/aceen/topics/ei/introduction/ei20

Albernaz, H. e. (2014). Implementation of Distribution Centers As Logistics Competitive Advantage: Study On Oil Company Distributor Ins Southeast Brazil. Independent Journal of Management \& Production , 5 (4).

Annan, K. F. (2012). Deepening Democracy: A Strategy for Improving the Integrity of Elections Worldwide. Global Comission on Election, Democracy and Security. , 6.

Azwar, S. (2010). Metode Penelitian. Yogyakarta: Pustaka Pelajar. 
Bawaslu, K. M. (2019). Laporan Akhir Hasil Pengawasan Pemilihan Umum Tahun 2019. Medan : Bawaslu Kota Medan.

Bawaslu. (2019). Pemutakhiran Indeks Kerawanan Pemilu 2019. Jakarta: Bawaslu.

Bungin, B. (2015). Penelitian Kualitatif: Komunikasi, Ekonomi, Kebijakan Publik, dan Ilmu Sosial Lainnya. Jakarta: Kencana Prenada Media.

Creswell, J. W. (2016). Research Design: Pendekatan Metode Kualitatif, Kuantitatif dan Campuran . Yogyakarta : Pustaka Pelajar.

DKPP. (2015). Penyelenggara Pemilu di Dunia: Sejarah, Kelembagaan, dan Praktik Pemilu di Negara Penganut Sistem Pemerintahan Presidensial, Semi Presidensial, dan Parlementer. Jakarta: DKPP RI.

Farisa, F. C. (2019, April 22). https://nasional.kompas.com/read/2019/0 4/22/21333871/kpu-total-2767-tpslakukan-pemungutan-suara-ulang-susulandan-lanjutan. Retrieved Desember 23, 2019, from https://nasional.kompas.com/: https://nasional.kompas.com/

Martono, R. V. (2018). Manajemen Logistik. Jakarta : Gramedia Pustaka Utama.
Mozaffar, S. a. (2002). The Comparative Study of Electoral Governance-Introduction. International Politicak Scieice Review , 23 (1).

Onstein, A. e. (2019). Factors determining distribution structure decisions in logistics: a literature review and research agenda. Transport Reviews , 39 (2).

RI, D. (2015). Penyelenggara Pemilu di Dunia: Sejarah, Kelembagaan, dan Praktik Pemilu di Negara Penganut Sistem Pemerintahan Presidensial, Semi Presidensial, dan Parlementer. Jakarta: DKPP RI.

Surbakti, R. d. (2011). Seri Demokrasi Elektoral Buku 11:Menjaga Kedaulatan Pemilih. Jakarta: Kemitraan bagi Pembaruan Tata Pemerintahan.

Torres, L. E. (2015). Electoral Governance: More Than Just Electoral Administration. Mexican Law Review , 8.

Van Thai, V. a. (2005). Van Thai, Vinh.,Selecting the Location of Distribution Centre in Logistics Operation: A Conceptual Framework and Case Study. Asia Pacific Journal of Marketing and Logistics , 17 (3). 